\title{
Study on Incentive Mechanism in the Construction of the Excellent Courses
}

\author{
Liu Jinxiang \\ School of Civil Engineering \\ University of South China \\ Hengyang, China \\ cafardworm@163.com \\ Chen Chunning \\ School of Civil Engineering \\ University of South China \\ Hengyang, China \\ chenchunning@163.com
}

\author{
Duan Qiongjin \\ Educational Administration Office \\ University of South China \\ Hengyang, China \\ Okmails@21cn.com \\ Li Shiyou \\ School of Civil Engineering \\ University of South China \\ Hengyang, China \\ lsy730723@163.com
}

\begin{abstract}
Construction of the fine courses is a dynamic and improving process. However, in many universities there emerges a problem that construction begins well while sequent assessment seldom goes on. The reason for this inharmonious phenomenon in linkage of the construction of the fine courses lies basically in the inadequate incentive mechanism that fails in inspiring the team's enthusiasm. To prompt this construction of fine courses, this paper makes some researches on the incentive mechanism, which is Establishing supportive models in floating fund, the evaluation mechanism, the exit mechanism of fine courses and Implementing post responsibility system for fine courses.
\end{abstract}

Keywords-incentive mechanism, construction, excellent courses, supportive models.

\section{INTRODUCTION}

Since the notification of launching teaching quality and teaching reform programme in construction of fine courses in higher education institutions by the ministry of education in 2003, some provinces and cities have carried forward the construction of fine courses in succession basically formed the construction system of fine courses with three-level among nation, province and university. The fine courses play a demonstration effect in its construction process; they influence and drive the construction of a series of courses, and however the fundamental aim of constructing fine courses is show its demonstration effect. Its requirements are as follows: update of the contents and its leading effect. Throughout the existing national and provincial fine courses, exquisite courses of some universities begins with "built" and ends with "review"[1], there is no basic change in update of content or network construction. Lack of maintenance fund on the one hand, lack of perfect incentive motivation, the initiative of the talented is not fully expressed.

\section{PRoblems CAUSED IN THE FINE COURSES CONSTRUCTION FOR LACK OF INCENTIVE MOTIVATION}

A. Scientific research in teaching on an unequal footing low enthusiasm of teachers' involvement in construction of fine courses

The evaluation way for most university (college) teachers is how their scientific research achievement is, the number of the published articles, status of application subjects are taken as title assess mandatory index, also their bonuses and performance-based wages have something to do with it. Due to the lack of "short, flat, faster" scientific research performance in teaching, many teachers would rather spend more time and effort on academic research than their will to title assess "no published doom"[2]. Teachers' personal energy seldom consider teaching, fine course construction becomes a motionless passive teaching, sometimes even becomes a teaching accessory couldn't be pushed; the whole effort of talent team of fine course construction is not fully developed.

B. Leading teachers alone enjoy the honor interests, teachers' enthusiasm change dramatically before and after evaluation

Most colleges regard the appraisal of national and provincial fine-selected courses as an honor for school, for this, each school before the review mobilizes enthusiasm from all parties in terms of financial support, teacher team construction and full support in network resources, once judged as national and provincial fine-selected courses, each work stops. The subsequent management of exquisite course is not in place, and leading teachers appraised in exquisite course are surrounded by honor, all kinds of media surrounded by stratified whoop on teachers to highlight the position of prominent leading teachers, exquisite course thus become the leading teacher and school brand, the honor and profit of leading teachers, all kinds of other related evaluations basically belong to the leading teacher, other individual 
participates in the construction enjoy few, even without honor interests, which seriously damages the other teachers' enthusiasm in participating in fine course construction, which led to the difficult subsequent management to promote fine courses, which basically becomes a matter of the leading teacher, the enthusiasm of team and group can not play.

\section{Lack of coordination between departments, one-sidedness exist in internal course construction}

Exquisite course construction is the construction of more than a department linkage process, involving college, staff room (department), educational administration office, modern education (many departments, such as network) in the declaration in the process of the exquisite course construction, each related department has done a lot of work, but as long as the national and provincial fine-selected courses appraised after, the honor and interests all belong to college, staff room (department) and teachers team, other related departments basically do not enjoy benefits, in later exquisite course construction, other indirectly related departments often lose the enthusiasm for construction, causing subsequent exquisite course construction and management difficult to coordinate, hard to push, website construction lags behind and linkage failure, untimely content update and upload etc. Meanwhile, exquisite course construction is conducted by the course director, who generally only considers internal reform for course, less consideration for contact other courses, lack of consideration how to drive the other main course construction with this exquisite course construction, etc. Some course construction has no high standing point and objectives, exquisite course construction can only stay in a level that has no contact with other course construction[3].

\section{Teachers are not willing to be hero behind the scenes for after-school job is invisible}

Much work in exquisite course construction relies on teachers after class, electronic lesson plans writing and frontier content update, web pages and websites style optimization, after-school network question-answering and counselling all depend on the teachers, and these are basically done in the spare time, work has been done a lot, but hard to reflect its essence, even hard to get the peer recognition, some teachers feel that work done but without achievement, they would rather develop their individual mien and reflect their individual value than do steadfast work behind the scenes, they are not willing to be like heroes behind the scenes.

\section{Perfecting the InCENTIVE MeChANISM TO PROMPT THE FINE COURSES CONSTRUCTION}

To prompt the construction of the fine courses, we must strengthen follow-up management in fine courses, on account of human factor, it is especially necessary to perfect the incentive mechanism.

\section{A. Establishing supportive models in floating fund}

According to the requirements of the Ministry of Education, the nation provides national and provincial fineselected courses every year with construction funds, provinces and cities and relevant universities are asked to prepare set, to promote the construction of well-designed courses, it is appropriate to adopt floating type fund rolling support patterns[4]. The competent administrative departments of education at all levels may take irregular way every year to check online courses already judged as well-designed courses, situation of check should be reported on time, and control should be proceeded in terms of construction funds, for subsequent management and inadequately constructed courses, to stir or postpone maintenance fund the next year in proportion to reduce construction funds, forming construction fund with floating system, adhere to the capital rolling support, increase financial support proportionally on good curriculum with exquisite course demonstration effect and soundly subsequent management and construction, forming the system of rewarding the good and fining the bad, mobilizing enthusiasm in high-quality course construction.

\section{B. Establishing the evaluation mechanism and perfect the incentive mechanism---guarantee of construction of fine courses}

Evaluation mechanism should change projected coursed into real well-designed ones under layers of scientific and strict supervision. Straighten out the management system and perfect the evaluation mechanism. In lateral management, establish school macro management, teaching supervision and guidance, organization and leadership of exquisite courses, the implementation of management system in course group or the teaching and research office, In longitudinal management, carry out the whole process of management : evaluation ----project approval-----construction-----review-----acceptance[5]. Link up the appraisal of project, mid-term assessment, curriculum acceptance and tracking survey organically and strictly manage each construction subject of exquisite courses.

\section{Strengthening review of fine courses, establish the exit mechanism of fine courses}

The ministry of education requires to review fine courses and gradually perfect the evaluation system, the time for reviewing the prophase construction of fine courses basically has already expired, the review is especially necessary to implement, demonstration effect of reviewing fine courses is not strong, and education resource sharing is not good enough, exquisite course that students benefit small should be promptly circulated, urge principals of high-quality goods to update and perfect, cancel its exquisite course titles for those can't really play a demonstration effect, to maintain pressure of schools, colleges, curriculum team construction of exquisite courses to promote the construction of fine courses in terms of system[6].

\section{Implementing post responsibility system for fine courses, strengthen the proportion of teaching in personnel titles appraisal}

In exquisite course construction process, we should carry out exquisite course post responsibility system, clarify course principals, leading teachers, the non-exquisite course leading teachers and the responsibility, right and interest of other staffs, through the post allowance, labor subsidies, project 
preferential, policy inclination, spiritual encouragement and so on, many kinds of ways to guide teachers actively take part in exquisite course construction[7].

Compared with scientific research, teaching achievements do not have quantified characteristics to a certain extent, but teachers in title appraisal are often qualitatively required of scientific research and quantitative paper, causing teachers' main energies go to scientific research work, but appear not so enthusiastic for teaching,. Therefore it's especially necessary to adjust the personnel title appraisal regulations, increasing the proportion of teaching in personnel title appraisal from the policy guidance, realizing the teaching and scientific research are equally important, such as exquisite course, professional academic leaders, teachers in teaching team in the title appraisal can have priority to be reviewed in equal circumstance, for teachers of exquisite course, professional academic foregoers in title appraisal, their research projects, quantities of thesis can be appropriately reduced to reflect the importance of teaching from personnel title appraisal and therefore to motive the teachers' enthusiasm in teaching.

\section{E. Reasonably converting teaching load, explicit benefit distribution method}

In fine courses construction, teachers after-school spend a great deal of painstaking effort updating the content, website construction and resources construction, time spent on these things is always called voluntary labor, which seriously damage teachers' enthusiasm in the construction of fine courses, so to participate in a certain proportion of construction of fine course each year in a certain amount of class teacher undertake convert, manifest teachers labor workload can stimulate the teachers' enthusiasm to work, while in all kinds of rewards, the interest distribution in highquality course construction should be made according to the teachers' practical work according to the proportion of the labor, which can clearly stimulate the fine course construction team's overall enthusiasm, promote teachers' participation in the fine course construction, truly building the course construction into well-designed courses.

\section{F. Strengthening training the young and middle-aged teachers}

Combining with the needs of the construction of fine courses, we carry out the training plan for the young teachers to develop their sense of responsibility and mission. In making the training plan, we should consider the reality of every young teacher, let them give full play to their specialized skill and make various types of talents come out as soon as possible. Second, through the organization of young teachers' viewing various education teaching research practice to develop their academic horizons. In this process, the course director will lead them to attend relevant teaching reform projects and teaching research topics, guide them to write teaching research papers and attend textbooks construction to guide and help young teachers unceasingly improve their teaching level and academic level. Make the young teachers willing to attend into the building fine courses.

\section{SUMMARY}

In all, fine course construction should not only prevent "built" in the beginning, "ended" at the evaluation, and to prevent the phenomenon of negative ideological effect, to truly build the fine course construction as a course with rich motivation, keen on innovation and constantly improved dynamic products, and realize the basic purpose of exquisite course construction.

\section{REFERENCES}

[1] Zhan Yunjun,Yuan Yanbing etal. The Problems and Suggestions of Construction of Excellent courses[J], Education Forum, 2014,04:239241.(in chinese)

[2] Shi Wenting, Study on Students' Innvoation Capability training in view of 11i'ational Essential Courses construction[D]. Nangjing University of Posts and Telecommunications, 2013. (in chinese)

[3] Liu Dehua,Liu Zhishen, Speculate of Problems on Construction of Excellent Courses, Education Forum, 2013,11:6-9. (in chinese)

[4] Dong Jianming,Li Wenshen etal. Speculate of Future Reform and Practice on Construction of Excellent Courses, China Power Education,2013,25:126-128. (in chinese)

[5] Liu Zhigang, Construction and Promote on Characteristic Mode of College Excellent Courses construction. 2012,18:12-14. (in chinese)

[6] Lian Ruomu, Analysis on Fine Courses in Colleges, China Education Innovation Herald, 2011,02:175. (in chinese)

[7] Chang Hao, The Problems of Website Construction of the High Quality Course and It s Solutions, Software Guide, 2010,08:189-191. (in chinese) 